www.jmscr.igmpublication.org

Impact Factor (SJIF): 6.379

Index Copernicus Value: 71.58

ISSN (e)-2347-176x ISSN (p) 2455-0450

crossref DOI:

Journal Of Medical Science And Clinical Research

\title{
Effect of Green Bean Porridge Modisco on the Changes of Albumin Level among Under-five children with below the red line (Case Study at the Work Area of Randublatung Public Health Center, Blora District)
}

\section{Authors \\ Atik Maria*, Suharyo Hadisaputro, Runjati Runjati, Donny Kristanto Mulyantoro, Melyana Nurul Widyawati}

${ }^{1}$ Magister Applied Midwifery, Postgraduate Program of Politeknik Kesehatan Kemenkes Semarang,

Semarang, Indonesia

*Coressponding Author

Atik Maria

Email: atikmaria41@yahoo.co.id

\begin{abstract}
Below the red line condition does not indicate malnutrition, but it is a warning for confirmation and follow-up. Providing green bean porridge to under-five children on a regular basis is very good because it contains various minerals, vitamins and even a very nutritious protein to spur growth. This study aims to prove that the provision of green beans porridge modisco can increase the albumin level of under-five children with below the red line. This is a Quasy Experiment with Pretest-Posttest with Control Group design. The sample size was 30 respondents, consisted of 15 children in the experimental group who were given green bean porridge modisco (10 grams of full cream milk, 5 grams of sugar, 5 grams of margarine, 60 grams of green bean porridge) and 15 children in the control group who were given 100 cc of green bean porridge. The study was conducted for 14 days. The measurement of albumin level used Bromo Cresol Green (BCG) method. The study showed a significant increase in albumin levels before and after intervention ( $p<0.05$ ) with an increase of $0.27 \mathrm{~g} / \mathrm{dl}$. Green beans porridge modisco could increase the albumin level of under-five children with below the red line compared to green bean porridge.

Keywords: Green bean porridge Modisco, Albumin
\end{abstract}

\section{Introduction}

Below the Red Line is a condition where underfive children have weight for age below the red line in 'Road to Health Chart' (RTHC), which does not always show under nourished or malnutrition but it is an early indicator that a child is experiencing a nutritional problem. Weight below the red line is a growth disorder in underfive children and it needs special care so that the child should be referred to a health centre/hospital. ${ }^{1}$

Under-five Mortality Rate in Central Java Province in 2014 amounted to 11.54/ 1,000 live births, decreased compared to 2013 with 11.80/1,000 live births. Compared to the expected coverage in the Millennium Development Goals (MDGs) in 2015 of 23/1,000 live births, Underfive Mortality Rate in Central Java Province in 
2014 has exceeded the target. The highest Underfive Mortality Rate was in Blora District of $19,73 / 1,000$ live births, while the lowest was in Surakarta of 4,09/1,000 live births. ${ }^{2}$

According to the guidebook of care to children with malnutrition, the management of undernourished children is done with supplementary feeding whereas malnourished children should get appropriate treatment for malnourished under-five children. ${ }^{3}$

The most nutritional problems in Indonesia is nutrient deficiency or that includes the imbalanced arrangement of food and overall insufficient consumption for the body. Under-five children (15 years old) are the most common age group suffering from malnutrition (PEM) or one of the community groups which is vulnerable to nutrition. $^{4}$

Factors that cause malnutrition, namely nutritional intake and understanding of safe food to eat, infectious diseases, the environment, access to health care and parenting. Lack of nutrients in children is caused by children getting food not in accordance with the needs of the child's growth or an imbalance between nutritional consumption and nutritional needs quantitatively and qualitatively. ${ }^{5}$ Malnutrition can occur in all age groups, but infants and under-five children groups need more care. ${ }^{6}$

Providing green bean porridge to under-five children regularly is very good because it contains various minerals, vitamins and even highly nutritious proteins to spur growth. 100cc of Modisco contains 130grams of calorie, 3 grams of protein, and 7.5 grams of fat. $^{7}$

\section{Method}

This study was a quantitative study with Quasy Experiment Design with Randomized Pre Test Plan Post Test Control Group Design. In this study the authors divided the two intervention groups namely the provision of green bean porridge modisco, and the provision of green bean porridge on the changes in the albumin level of under-five children with below the red line.
The population in the study was all under-five children with below the red line. The samples in this study were chosen by using probability sampling technique with Simple Random sampling technique by determining the serial number, the samples who got the odd serial number were included in the intervention group and the samples who got the even serial number were included in the control group.

The data in this study were obtained from respondents and data from Public Health Centre. Data from the respondents were obtained from questionnaires filled by the respondents during pre and post-test. The questionnaire provided short answered questions in accordance with the identity of respondents.

Bivariate analytic was initialed with a data normality test to know data characteristics, and then data were presented in table form. Normality test used Shapiro-Wilk Test. There was a test using Levene's test to know the variance between the two groups of respondents whether the same (homogeneous) or not. Based on the homogeneity test results, the confounding variables of age, education and occupation showed no difference in the means between the two intervention groups so it can be concluded that both intervention groups were in a homogeneous state. This reflects that the influence of interventions impacting the increase of albumin levels and growth to each intervention group has an effect of the intervention given. Normality test data used here was Shapiro-Wilk test because the number of respondents was less than 50 .

\section{Result}

\section{Characteristics of Respondents' Mothers}

The characteristics of respondents' mothers in this study include: age, education and occupation. Characteristics of respondents can be seen in the Table 1. It showed homogeneity in the Characteristics of the samples based on age, which proved that the means of the experimental group and the control group were the same. So, there was no significant difference in the means of age 
between the experimental group and the control group $(\rho=0,502)$. Characteristics of the samples based on education showed a homogeneity which proved that the means of the experimental group and the control group were the same. So, there was no significant difference in the means of education between the experimental group and the control group $(\rho=0.579)$. Characteristics of the samples based on occupation showed a homogeneity which proved that the means of the experimental group and the control group were the same. So, there was no significant difference in the means of occupation between the experimental group and the control group $(\rho=0.292)$.

Table 1. Characteristics of respondents' mothers based on age, education and occupation in the Control Group and the Experimental Group At Randublatung PHC.

\begin{tabular}{|c|c|c|c|}
\hline \multirow[b]{2}{*}{ Variable } & \multicolumn{2}{|c|}{ Group } & \multirow[t]{2}{*}{ o Value } \\
\hline & $\begin{array}{c}\text { Experiment } \\
(n=15)\end{array}$ & $\begin{array}{l}\text { Control } \\
(n=15)\end{array}$ & \\
\hline $\begin{array}{l}\text { 1. } \text { Age } \\
\text { a. Mean } \pm \text { SD } \\
\text { b. Min-max }\end{array}$ & $\begin{array}{c}28,00 \pm 3,82 \\
21-35\end{array}$ & $\begin{array}{c}27,67 \pm 4,35 \\
21-36\end{array}$ & $0,502^{1}$ \\
\hline $\begin{array}{l}\text { 2. Education } \\
\text { a. Mean } \pm \text { SD } \\
\text { b. Min-max }\end{array}$ & $\begin{array}{c}1,80 \pm 0,68 \\
1-3\end{array}$ & $\begin{array}{c}2,07 \pm 0,79 \\
1-3\end{array}$ & $0,579^{1}$ \\
\hline $\begin{array}{l}\text { 3. Occupation } \\
\text { a. Mean } \pm \text { SD } \\
\text { b. Min-max }\end{array}$ & $\begin{array}{c}1,67 \pm 0,49 \\
1-2 \\
\end{array}$ & $\begin{array}{c}1,67 \pm 0,62 \\
1-3 \\
\end{array}$ & $0,292^{1}$ \\
\hline
\end{tabular}

\section{Albumin Levels}

Table 2 Difference of Albumin Level in the Control Group and the Experiment Group in the Work Area of Randublatung PHC.

\begin{tabular}{|c|c|c|c|}
\hline \multirow[t]{2}{*}{ Variable } & \multicolumn{2}{|c|}{ Group } & \multirow[t]{2}{*}{ 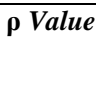 } \\
\hline & $\begin{array}{l}\text { Experiment } \\
\quad(\mathbf{n}=15)\end{array}$ & $\begin{array}{l}\text { Control } \\
(n=15)\end{array}$ & \\
\hline $\begin{array}{l}\text { 1. Before } \\
\text { intervention }\end{array}$ & $3,96 \pm 0,39$ & $4,2 \pm 0,38$ & $0,200^{1}$ \\
\hline $\begin{array}{l}\text { a. } \text { Mean } \pm \text { SD } \\
\text { b. } \text { Min-max }\end{array}$ & $3,2-4,6$ & $3,6-5,0$ & \\
\hline $\begin{array}{l}\text { 2. After intervention } \\
\text { a. Mean } \pm \text { SD } \\
\text { b. Min-max }\end{array}$ & $\begin{array}{c}4,33 \\
3,9-5,2\end{array}$ & $\begin{array}{c}4,24 \pm 0,39 \\
3,6-5,0\end{array}$ & $0,403^{1}$ \\
\hline $\begin{array}{l}\text { 3. The difference of } \\
\text { Albumin level } \\
\text { a. Mean } \pm \text { SD }\end{array}$ & & & $0,000^{3}$ \\
\hline b. Min-max & $\begin{array}{c}0,37 \pm 0,24 \\
0,1-0,8\end{array}$ & $\begin{array}{c}0,04 \pm 0,05 \\
0,0-0,1\end{array}$ & \\
\hline \multirow[t]{2}{*}{$\begin{array}{l}\text { 4he difference } \\
\text { before }- \text { after } \\
\text { intervention } \\
\text { P value }\end{array}$} & & & \\
\hline & $0,001^{2}$ & $0,000^{2}$ & \\
\hline
\end{tabular}

Table 2. showed that the mean of albumin level in the experimental group before the intervention was $3.96 \pm 0.39$ while the mean in the control group was $4.2 \pm 0.38$. Independent $\mathrm{T}$-Test result obtained $\rho$ value $=0.200$ which meant that there was no significant difference in the mean of albumin level before the intervention between the experimental group and the control group. The mean of albumin level in the experimental group after intervention was 4.33 whereas the mean in the control group WAS $4.24 \pm 0.39$. Independent T-Test result obtained $\rho$ value $=0,403$ which meant that there was a significant difference in the mean of albumin level after the intervention between the experimental group and the control group.

The mean of the albumin level difference in the experimental group was $0.37 \pm 0.24$ whereas in the control group the mean of albumin level difference was $0.04 \pm 0.05$, the Mann-Whitney Test result obtained $\rho$ value $=0,000$ which meant that there was a significant difference in the mean of albumin level difference between the experimental group and the control group.

The mean in the experimental group before the intervention was $3.96 \pm 0.39$, the mean after intervention was 4.33. The analysis result of albumin levels before and after the intervention in the experimental group with Paired T-Test obtained $\rho=0.001$ which meant that there was a significant increase in albumin level after the intervention so that there was an effect of green bean porridge modisco on the albumin levels before and after the intervention. The mean in the control group before the intervention was $4.2 \pm$ 0.38 , the mean after the intervention was $4.24 \pm$ 0.39 . The analysis result of albumin levels before and after intervention in the control group with Paired T-Test obtained $\rho$ value $=0,000$ which meant that there was no significant increase in the mean of albumin level after the intervention so that there was no effect of green bean porridge on the albumin levels before and after the intervention. 


\section{Discussion}

The study result showed that there was a significant difference of albumin levels between the experimental group and the control group before the intervention was given with a significance value of 0.200 . In this study the experimental group was given intervention in the form of green bean porridge modisco $100 \mathrm{cc} /$ day while in the control group was given green bean porridge, both groups were given once a day for 2 weeks and showed that there was a significant difference between the experimental group and the control group after the intervention with a significance value of albumin level of 0.403 .

The plasma albumin concentration is one of the important indicators in an assessment of nutritional status. Lack of nutrients that occur continuously will result in low serum albumin concentration as a result of protein deficiency, with other signs as follows: 1) Slow growth, 2) Weight loss, 3) Decreased achievement, 4) Low breast milk production during lactation, 5) Dull and rough hair and others. ${ }^{8}$ In addition, low albumin concentration will result in other nutrients, such as calcium because the calcium in the blood binds to albumin. Normal level of serum albumin concentration depends on 3 factors: Biosynthesis rate, Volume and characteristics of the distribution space, and Catabolism rate. ${ }^{9}$

Albumin synthesis requires about $6 \%$ of nitrogen intake per day. Hepatocytes in the liver at the time of albumin synthesis require a rate of 120 to 270 $\mathrm{mg} / \mathrm{kg}$ body weight per day. The rate of albumin biosynthesis is influenced by the intake of protein, temperature and plasma oncotic colloidal pressure in the vicinity of the biosynthesis space. ${ }^{7}$

Normal total albumin level in the body ranges from 3 to $5 \mathrm{~g} / \mathrm{kg}$ body weight, and 30 to $40 \%$ of the value is in the intravascular space. Extravascular albumin is present in the entire soft tissue and about half of it is in the skin. In children who experience below the red line, the movement of albumin begins from the extravascular space to the intravascular. The main site of albumin catabolism is the intestine and vascular endothelium. The rate of catabolism is increased due to physiological stress, hypermetabolism and the presence of Cushing's syndrome and some types of tumors. The rate of albumin catabolism decreases when nutrient deficiency and hypometabolism present. However there are still many other factors that affect the distribution and catabolism of albumin. ${ }^{10}$

A change in albumin motion is mainly due to food intake response, which leads to the change in the rate of synthesis. A person with low protein energy intake will have a decrease in the synthesis rated rapidly and consequently the balance of albumin becomes negative. When the intake remains low then the catabolic speed of albumin decreases and eventually leads to a decrease in the overall rate of albumin in the body. ${ }^{11}$

Three interrelated factors which directly affect albumin metabolism are: PEM, Physiological Stress and lack of protein intake. These three factors result in a series of albumin synthesis, catabolism, distribution and hydration processes that will ultimately affect serum albumin level. ${ }^{8}$

In this study, the results of albumin level analysis before and after the intervention in the experimental group obtained $\rho=0.001$ which meant that there was a significant increase in albumin level after the intervention, so there was an effect of green bean porridge modisco to the albumin level before and after the intervention.

The results of this study are also in line with study which concluded that the provision of dietary supplement with biscuit made of tempeh in a relatively long time would improve the weight and blood albumin. ${ }^{12}$ It can be explained that the direct intake of nutrients will affect the nutritional status of a person, meaning that if the amount of nutrient intake derived from food consumed increases, then the nutritional status will also increase. In addition, the normal or physiological increase of age also affects the increased consumption of food, so the amount of nutrient intake also increases. ${ }^{13}$ Before providing complementary food, measurement of albumin level was conducted in both groups. The mean of albumin level in the 
biscuit group before the intervention was higher (5.42) than in the FTB group (5.07), but no significant difference was observed after the independent sample t-test ( $p>0,05)$.

The measurement result showed that there was a difference of albumin level before and after intervention ie -0.28 ( $\pm 0.58 \mathrm{SD})$ in biscuit group. Furthermore, the statistical test results also showed that there was a significant difference. It indicated that there was a significant difference in the mean of albumin level before and after the intervention with $p=0.047(p \leq 0.05)$ in the biscuit group, but not significant in the FTB group ( $\mathrm{p}>$ 0.05). Complete difference of albumin level before and after intervention.

This study is in line with the study of tempeh-bran biscuit of fortified $\mathrm{Fe}$ and $\mathrm{Zn}$ had no significant effect on the increase of albumin level. In this study it was found that the mean of albumin level was decreased after biscuit provision but the changes produced were still within the limit of normal albumin level. ${ }^{14}$

One laboratory index of protein status measurement is the visceral protein status that is often used to estimate the serum total protein, albumin, transferrin, pre-albumin, and retinol binding proteins measurements. Albumin is the main protein in human plasma (3.4-4.7 $\mathrm{g} / \mathrm{dl}$ ) and makes up about $60 \%$ of the total plasma protein secreted by the liver into the blood. Approximately $40 \%$ of albumin presents in plasma, and another $60 \%$ is found in the extracellular space. ${ }^{15}$ The albumin level can be measured by spectrophotometric method.

Serum albumin level is influenced by several factors, namely (a) lack of protein intake, caused by poor food intake, anorexia, unbalanced food consumption; (b) metabolic changes due to injury, stress, sepsis, and hypoxia; (c) a specific deficiency in protein plasma from protein-losing enteropathy and liver disease; (d) decreased protein synthesis due to lack of energy intake, electrolyte deficiency, micro mineral deficiency (iron and zinc), vitamin A deficiency; (e) pregnancy that causes changes in the amount and distribution of body fluids; (f) changes in capillary permeability; (g) drugs; (h) strenuous exercise. ${ }^{16}$ Furthermore, an analysis of the difference in the changes in albumin level between groups was obtained. The result of independent sample t-test on the difference in the changes in albumin level between groups can be seen in Table 2. The result of statistical test showed no significant difference in the mean changes difference in albumin levels between groups ( $p>0.05$ ). This showed that between the provision of tempeh-yam and biscuit formulas altogether made changes to the children's albumin level but the changes were not statistically significant. Several other studies have shown that the growth of children who got soy or tempeh formula was no different from that of children who got cow's milk formula and breast milk. Infants who go the tempeh formula had normal growth and development, normal serum albumin and haemoglobin. ${ }^{10}$

Synthesis of protein in the liver, especially albumin synthesis is very responsive to the influx of amino acids from food. If protein intake increases then albumin synthesis will also increase. Albumin as a body protein transport that indicates protein status is a response of food consumption, especially food as the sources of protein, although there were inconsistent data. This was due to the presence of several factors that affected the protein concentration in the blood. Factors that also caused decreased level of protein transport material in addition to protein consumption deficiency were energy deficiency, zinc deficiency, infection, and liver disorders. ${ }^{9}$

\section{Conclution}

Based on the above information, it can be concluded that the provision of green bean porridge modisco could increase the level of albumin among under-five children with below the red line.

\section{References}

1. Wong, D L. Textbook on Pediatric Nursing. Vol 1. $6^{\text {th }}$ edition Jakarta. 2009. 
2. Health Department. Health Profile of Blora District Health Office, Blora District Health Office. 2014.

3. Blora District Health Office. Guidelines for Nutritional Status Monitoring. Central Java. 2016.

4. Health Department of the Republic of Indonesia. Basic Health Research, Research and Development on Health, Health Department of the Republic of Indonesia. 2010.

5. Moehji, S. Ilmu Gizi 2. Papas SinarSinanti. Jakarta. 2003. 302-62

6. Jelliffe DB, EFP Jelliffe.1989. Community Nutritional Assesment with Special Reference to Less Technically Developed Countries. Oxford. Oxford Universitas Press

7. Akre, J, 1994. Baby Feeding, Physiological Basics. FKM. UI, $1^{\text {st }}$ edition, Jakarta.

8. Soekirman. The science of nutrition and his application , to family and community.2010.

9. Sacher RA. Tinjauan klinis hasil pemeriksaan laboratorium. 2010.

10. Murray RK. Plasma Protein \&Immunoglobulins. In: Murray, R.K. Granner, D.K., Rodwel, V. W. (eds). Harper's Illustrated Biochemistry. 2006.

11. Kamalia A. The Nutritive Therapy of Modified Modisco with Pineapple Extract Increase Haemoglobinon Severe Protein Energy Malnutrition Rat.e-. 2014;vol. 2 (no. 1).

12. Arifin. Nd. Factors that affects malnutrition in toddlers in the village KarangrejoLor, Kecamatan Jakenan, KabupatenPati (epidemiology malnutrition). 2007.

13. WHO. Complementary Feeding. Medical Books Publisher EGC, Jakarta. 2008.

14. Milan CVdR, Milan I-20142. Nutritional assessment and risk of malnutrition in hospitalised children in northern Italy. Carlo Agostoni, Pediatric Clinic 2, Department of Clinical Sciences and Community Health, Fondazione IRCCS Ospedale Ca Granda-
Ospedale Maggiore Policlinico, University of, Italy. 2014.

15. Moejhi, Basic Knowledge of Nutrition Science. Gramedia, Jakarta.2009.

16. Irawan $\mathrm{R}$. The difference speed healing malnourished children who were given formula milk and Modisco Formula Elemental di RSU Dr Soetomo Surabaya. 2006. 